\title{
Noches, sueños y apariciones de un fin de siglo. Odilon Redon en la Colección Ian Woodner
}

\author{
Kafina Marotta Peramos
}

"He sufrido todos los tormentos de la imaginación y las sorpresas que me procuraban bajo el lápiz..." ${ }^{1}$. Así hablaba Odilon Redon en un momento dado de su vida refiriéndose a su obra pasada. En efecto, él fué un significativo eslabón en una cadena que se inicia con el Romanticismo y cuyos ecos hoy seguimos viviendo. Como sus predecesores, Blake, Füssli y tantos otros, sintió la llamada del inconsciente, del más allá. De mundos y seres desconocidos.

Esta llamada de otros territorios tiene sus raíces en el final del siglo XVIII e inicios del XIX, tras el cataclismo de la Revolución Francesa. Ella supuso romper con una serie de cánones e ideas que habian guiado al hombre ilustrado. Tras ella, muchas normas se vinieron abajo. El Arte se liberaliza. Pierde su encorsetamiento, y al tiempo pierde también su rumbo: ser artista ya no consiste en "saber hacer" algo, sino que se convierte fundamentalmente en ser capaces de inventar. El creador, cuyo reino ya no es de este mundo, debe imaginar seres y temas que devuelvan al Arte la emoción perdida. Hay un afán de sorprender, de provocar incluso. El Arte, en palabras de Angel González, "se convierte en una máquina de excitar".

El artista se inventa nuevos mundos porque el que tiene, el real, no le satisface y, sobre todo, no le responde. El diálogo entre el hombre y

Catálogo de la exposición Odilon Redon. Colección lan Woodnek, Madrid, Fundación Juan March, 1989, pág. 24. 
la naturaleza ha enmudecido. El hombre está solo. Freud dice que «artista en general es un hombre que ha salido de la realidad porque no puede hacer las paces con ella»?

Surgen los monstruos, los seres hibridos, y sobre todo, los sueños. El descubrimiento del sueño, de la noche y de sus criaturas es uno de los mayores logros románticos y las artes hacen de ellos los protagonistas: "La scoperta dell'orrore come fonte di diletto e di bellezza fini per reagire sul concetto stesso della bellezza: l'orrido, da categoria del bello, fini per diventare uno degli elementi propri del bello: dal bellamente orrido si passó per gradi insensibili all' orribilmente bello" ${ }^{3}$.

Esta situación de desamparo, de soledad, según Sedimayr ${ }^{4}$ podría ilustrarse mediante una metáfora: en 1842, Adalbert Stifter realiza una magnífica descripción de un eclipse de sol. Este eclipse no es sólo un fenómeno físico, sino también metafísico. El hombre ha perdido su luz interior, y por ello, de una parte se recrea en la contemplación nocturna, pero de otra, busca, ansia la luz. Afirma lord Byron que «los hombres incendian sus casas para no ver más que luz".

Vemos por tanto, que hay toda una tradición irrealista que avanza a lo largo del siglo XIX y llega hasta el presente. El desarrollo más evidente de esta cadena sería el que va desde el Romanticismo al Surrealismo pasando por el Fin de Siglo europeo.

Naturalmente, la visión de la noche, de los sueños y de la muerte (obviamente conectada con ellos) cambiará con el tiempo y según el creador que la trate, pero hay una serie de constantes que se dan en todo momento, pues se han convertido en categorias antropológicas. A este respecto, es esclarecedor el análisis que Cesare Segre lleva a cabo sobre la imágen que el hombre se crea del más allá. Del otro mundo se imaginan horrores inconcebibles en este, torturas, visiones, sufrimientos, tinieblas, rechinar de dientes... elementos todos que ya estaban presentes en los textos de los profetas bíblicos y que, transformados en imágenes visuales, podemos encontrar en la obra de Redon.

El paso de un mundo a otro, de la vigilia al sueño (¿no es el sueño ya una prefiguración de la muerte?) está lleno de fascinación y misterio. Se trata de captar el instante en el que de la vida se pasa a la muerte.

WeRner, A., The graphic work of Odilon Redon, New York, Dover, 1969, pág. XIII.

${ }^{3}$ PRAZ, M., La carne, la morte e il diavolo nella letteratura romantica, Milano-Roma, La Cultura, 1950, pág. 25.

${ }^{4}$ Sedlmayr, H., La muerte de la luz, Caracas, Monte Ávila, 1969, pág. 12. 
En este sentido, «il concetto di vita $\leftarrow$ morte BARRIERA é un archetipo universale, tanto più che la barriera impedisce la reversibilità vita $\leftarrow$ morte, almeno a chi non sia investito di qualche missione soterica o poeticas ${ }^{5}$.

Estas visiones de muerte, estos sueños convulsos, apelan claramente al estado de embriaguez mental o de ensueño en el que, pese a lo que parecia antonces, gracias a los estudios comenzados por Jung y Freud, sabemos que hay una lógica, una sintáxis del todo propia que se hace fundamental conocer para el que se va adentrar en aquellos mundos, y que nos comunica mensajes que hay que descifrar. Habrá que ir más allá de la imágen concreta y descubrir los significados, pues el léxico de este lenguaje no es siempre univoco. El soñador, por definición, vive absorto y deslumbrado por sus propios mundos. Esa capacidad de ver más allá es su característica esencial.

Hemos dicho que la noche fue un descubrimiento romántico, pero a lo largo del $x \mid x$, el tratamiento que se le dio al tema fue variando, según unos más ostensiblemente, según otros menos ${ }^{6}$. Realmente, la fascinación que escritores y pintores sintieron por lo nocturno permaneció intacta. Sin embargo, sería conveniente señalar algunos de sus rasgos y su evolución hasta el Fin de Siglo.

Ante todo, la noche, para el poeta de inicios de siglo, es confortadora, reparadora. Es el tiempo de los enamorados, del genio y, para muchos, de la paz consigo mismos. Es el intento de comunión con la naturaleza, el retorno al origen, a la Madre. Es la felicidad perdida, esa que obsesiona al hombre romántico y por la que el Arte deberá consolarle, esa que a veces aflora en el sueño como una ilusión. El poeta romántico exclama: “¿Qué alegria, qué bendición es el adiós del dia!».

Este encuentro con la naturaleza es también encuentro con la divinidad. Para Runge, es el momento en el que nos conocemos a nosotros mismos, a la verdad y a Dios. La noche es la portadora de la fuerza de la vida. Tiene esa energía dionisiaca que hace de ella la vitalidad y por la que Nietzsche la ensalza por encima del dia en Asi habló Zaratustra?. Por ello, alguien apegado - al menos en un primer momento- a la luz como Goya, recurre como otros ilustrados a las tinieblas. La relación con

5 Segre, C., Fuori del mondo. I modelli nella follia e nelle immagini dell'aldilá, Torino, Einaudi, 1990, pág. 18.

${ }^{6}$ Praz, M., obra citada, pág. $V$ opina que las manifestaciones de Fin de Siglo no son sino un mero desarrollo del Romanticismo.

7 NietzSChe, F., "Canción de medianoche", en Asi habló Zaratustra, Madrid, Edaf, 1974 , pág. 71. 
ellas es ambigua: de una parte se enfrenta a ellas para destruirlas, y destruir también a sus criaturas, pero al mismo tiempo, en esta confrontación, siente la fascinación del monstruo nocturno y, al fin, no puede liberarse de su fuerza.

Sin embargo, también la noche es misterio, terror y temor, sueño convulso. Es, en suma, la prefiguración de la muerte y de los tormentos infernales. El hombre romántico se siente atemorizado por estas imágenes de apariciones, pero, al mismo tiempo, subyugado. No quiere renunciar a ellas, pues su imaginación, que se nutre de sueños, siente con estas imágenes, la fuerza de la vida. La imaginación es lo único que le queda al hombre. Hölderlin dirá: «El hombre es un dios cuando sueña y un mendigo cuando reflexiona" ${ }^{\circ}$.

Lord Byron exclama: «Noche, no fuiste entregada al hombre para dormir». Las tinieblas son, por su encanto y belleza, el momento de la inspiración. En 1816, en Ginebra, envuelto por esta atmósfera, Byron, en compañía de Mary y Percey Bysshe Shelley, Polidori y M. G. Lewis, transcurre unas noches. Juntos leen historias de misterio y Mary crea a su Frankenstein, criatura de la que nunca más se separará.

En esa misma ocasión, Polidori escribe su Vampiro. Es ésta otra de las criaturas nocturnas por excelencia. Su perfil tiene mucho que ver con el del héroe inconformista byroniano. Es desdichado, como Frankesnstein porque destruye lo que ama.

Afortunadamente, todos estos temores desaparecen con la luz del día. Tras la noche viene la calma, el espectáculo de la vida. Como en el eclipse de Stifter, tras la convulsión, todo vuelve a su orden. Queda todavia un poco de cordura, de equilibrio. A los hombres de Fin de Siglo no les quedará ya esto.

De hecho, la noche de Ensor, Klimt o el primer Redon será mucho más amarga. Pocas veces será ya esa madre (o madrastra) confortadora. Es el encuentro del hombre consigo mismo y con sus monstruos, su soledad y su locura. No llegará el dia reconfortante. En 1898 encargan a Klimt la realización de unos paneles decorativos para la Universidad de Viena, con una idea general muy concreta: el triunfo de la luz sobre las tinieblas. Ninguno de estos tres paneles refleja tal triunfo. Priman los instintos, el subconsciente, la fuerza dionisiaca, no la luz.

${ }^{8}$ Cita tomada de: Argullol, R., La atracción del abismo. Un itinerario por el paisaje romántico, Barcelona, Plaza y Janés, 1987, pág. 63. 
Las imágenes nocturnas de Fin de Siglo se gestan bajo la idea que sirve de denominador común de que todo es mutable, tanto el mundo fenoménico como la propia frontera entre sujeto y objeto. No hay realidad concreta alguna, ni mucho menos certeza sobre nada. Hofmannsthal hace exclamar a uno de sus personajes: "Todo se quebró en partes y esas partes volvieron a dividirse en más partes y ya nada se permitió ser abarcado por conceptos" ${ }^{9}$.

En efecto, el Fin de Siglo contiene unas imágenes nocturnas escalofriantes. Vallotton, o el propio Redon nos presentan frecuentemente imágenes como "Visión. Dientes de Berenice" (Fig. 1) que son puras alucinaciones. Si el Romanticismo nos presentaba la dramática relación de escisión del hombre con la naturaleza, ahora muchas veces no encontraremos figura humana alguna. El paso final será el Surrealismo en cuyos paisajes la huella del hombre habrá desaparecido.

Sigue predominando esa "estetica dell'orrido" a que se refería $M$. Praz. Abundan las imágenes escalofriantes e infernales. Baudelaire, para quien la imaginación era la más alta de las facultades humanas, en su Hymne à la Beauté considera que Satán es el máximo de la belleza: “Appuyé sur - d'autres diraient: obsédé par-ces idées, on conçoit qu'il me serait difficile de ne pas conclure que le plus parfait type de Beauté virile est "Satan" à la maniére de Milton" ".

Son noches de horror y pesadillas. Huysmans, en su $A$ Rebours, hace declarar a su protagonista que la contemplación de la obra de Redon le hace pensar en antiguas pesadillas $y$ noches de infancia enfermiza ${ }^{11}$.

El apelar a las fuerzas infernales es rasgo común del momento. Alguién tan metódico como Freud las evoca en su Interpretación de los sueños. En esta obra introduce la leyenda latina "Flectere si nequeo superos, Acheronta movebo" (Si no puedo conciliar a los dioses celestes, moveré a los del infierno -el río Aqueronte-). Efectivamente, esta fascinación por la noche, el inconsciente y su misterio no se sustrajo a los intereses del médico vienés, sólo que él convirtió sus obsesiones y ensoñaciones en un discurso científico riguroso. Su mérito fue ante todo el de descubrir y demostrar una lógica a los sueños, desentrañar sus significados y llegar a la conclusión de que estas pesadillas no eran más

${ }^{9}$ Schorske, C. E., Viena Fin-de-Siècle. Política y Cultura, Barcelona, Gustavo Gili, 1981, pág. 41.

10 PrAZ, obra citada, pág. 28.

"Referencia tomada de: Delevoy, Diario del simbolismo, Destino-Skira, 1979, pág. 63. 


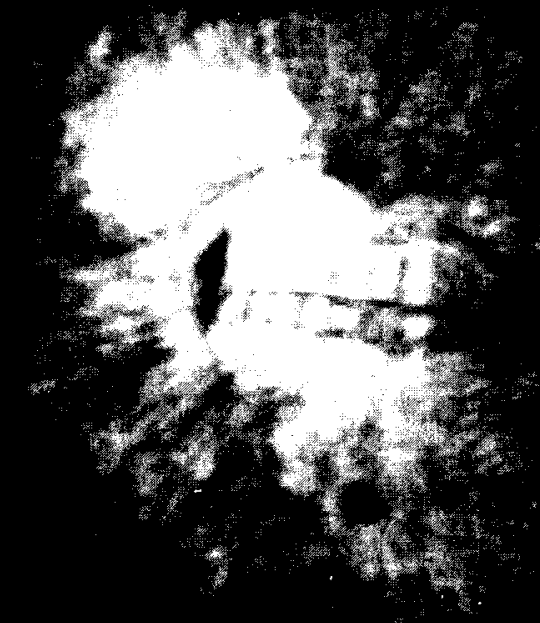

Fig. 1. "Vision: dientes de Berenice", s/f. 
Noches, sueños y apariciones de un fin de siglo. Odilon Redon ...

que manifestaciones de deseos insatisfechos. No se trata ya de huir de esta realidad, sino de estudiar la otra, la del sueño, para relacionarla con esta.

La relación tan familiar con otros mundos creados por el propio subconsciente, internos a nosotros, fue algo generalizado en el Fin de Siglo, especialmente el vienés. De hecho, las crisis política y social hicieron al intelectual del momento replegarse en si mismo, en su propio interior, con una voluptuosidad y languidez casi enfermizas.

Precisamente la voluptuosidad y la sensualidad son rasgos que se acentúan en la noche del Decadentismo y Simbolismo. En el Romanticismo también se había dado a la noche una carga erótica, pero es ahora, con la consolidación del mito de la mujer fatal, cuando este rasgo se desarrolla e incluso se hipertrofia. Todo artista del momento, desde Rossetti hasta Khnopff tiene en su repertorio mujeres malignas y voluptuosas. Ellas son las que asustan al hombre y lo vencen. Con ellas se mantiene una relación de amor/deseo/temor/odio. La mujer, como criatura de la noche, lunar, aparece como ensueño, como amada, y por último, como pesadilla. "En la tierra soy una sombra reflejada en el espejo, de noche, cuando tú te sumerges en el sueño, fuego líquido" ${ }^{12}$. La unión con la mujer sólo se podrá llevar a cabo a través de la muerte. Baudelaire habla de la mujer negra que "despierta el deseo de morir lentamente bajo su mirada" ${ }^{13}$. Veremos que el tratamiento que Redon da a la mujer está dentro de esta línea.

Compañero de Gauguin, de Degouve de Nuncques, de Puvis Chavannes, Redon, pese a que muchos le designaron como maestro, nunca quiso que le alinearan en ningun grupo. De hecho, encuadrarle es difícil: por evolución y personalidad, destaca en muchos aspectos y sobre todo transciende el reducido ámbito de una escuela.

Su interés por la ensoñación, por mundos interiores, es muy caracteristica de su obra. A lo largo de su vida, tendrá cambios importantes en su trayectoria, pero sus obras nunca perderán ese aura de obra soñada, poética, intuida. Su relación con la naturaleza fue compleja. En realidad, nunca se apartó de ella, pues de ella provenia su inspiración y su observación. Sin embargo, opinó que el modo de aproximarse al

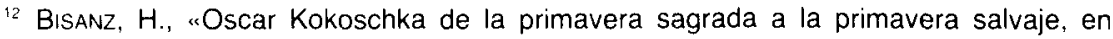
Debats, núm. 18, 1986, pág. 44.

13 BaudelalRe, C., "El deseo de pintar", recopilada en: AA.VV., Simbolismo. Soñadores $y$ visionarios, Madrid, Tablate, 1984, pág. 117. 
mundo objetivo que tenían otros artistas contemporáneos suyos era errónea: consideraba que los impresionistas eran unos esclavos de la realidad, parásitos del objeto. Ellos nunca habian intentado ir más allá, cosa que fue, por otra parte, el interés principal de Redon, aún dejando siempre muy claro que partía de la realidad. Frencuentemente, se quejaba de que los artistas contemporáneos a él pintaban lo que veían y no lo que soñaban.

Por ello, este creador siempre presenta el mundo de forma tangible, verosímil, pero no puede limitarse sólo a esto. De hecho, frecuentemente recordaba cómo sufría cuando, estudiando en la Academia, le obligaban a inscribir las formas dentro de una línea: "Me aconsejaba encerrar en un contorno una forma que yo veía palpitante» ${ }^{14}$.

Renato Barilli ${ }^{15}$ pone en relación ese interés de Redon por plasmar la realidad trascendiéndola, con el Surrealismo, pues los artistas de este grupo también trataban de reflejar otros mundos haciéndolos plásticamente "perfectos", fieles a la realidad visible. Odilon resume la esencia de su pintura en una frase: "Toda mi originalidad consiste pues, en hacer vivir humanamente a seres inverosimiles conforme a las leyes de la verosimilitud, poniendo, en lo posible, la lógica de lo visible al servicio de lo invisible" ${ }^{16}$.

Para llevar a cabo esta disección de la naturaleza, utiliza, en un primer momento, el carboncillo negro. Por medio de él, podía aproximarse al objeto minuciosamente. De hecho, le interesan enormemente los aparatos que permitan una observación de la naturaleza más rigurosa. Su amigo Clavaud, botánico, le introduce en el mundo del microscopio y, en ese orden de cosas, Redon será muy amigo de estos "forzamientos" de la realidad: le fascinará tanto lo infinitamente pequeño como lo inmensamente grande a través de visiones telescópicas, de galaxias y constelaciones. Redon es muy amante de estas imágenes cósmicas en las que, como en su serie litográfica Dans le Reve de 1879, los planetas tienen rostros humanos (Fig. 2).

Es el negro, ya sea a carboncillo o con yeso litográfico, el que le proporciona estas calidades misteriosas que tienen sus dibujos y grabados. Denominó a sus primeras obras Los negros. Para él éste es un agente del espíritu, mientras que el color "rebaja" a los dibujos. Por otra

${ }^{14}$ Odilon Redon. Colección lan Woodner, obra citada, pág. 21.

${ }^{15}$ BarILLI, R., I/ simbolismo. Le immagini dell'idea, Milano, Fratelli Fabbri, 1967.

${ }^{16}$ Odilon Redon. Colección lan Woodner, obra citada, pág. 25. 


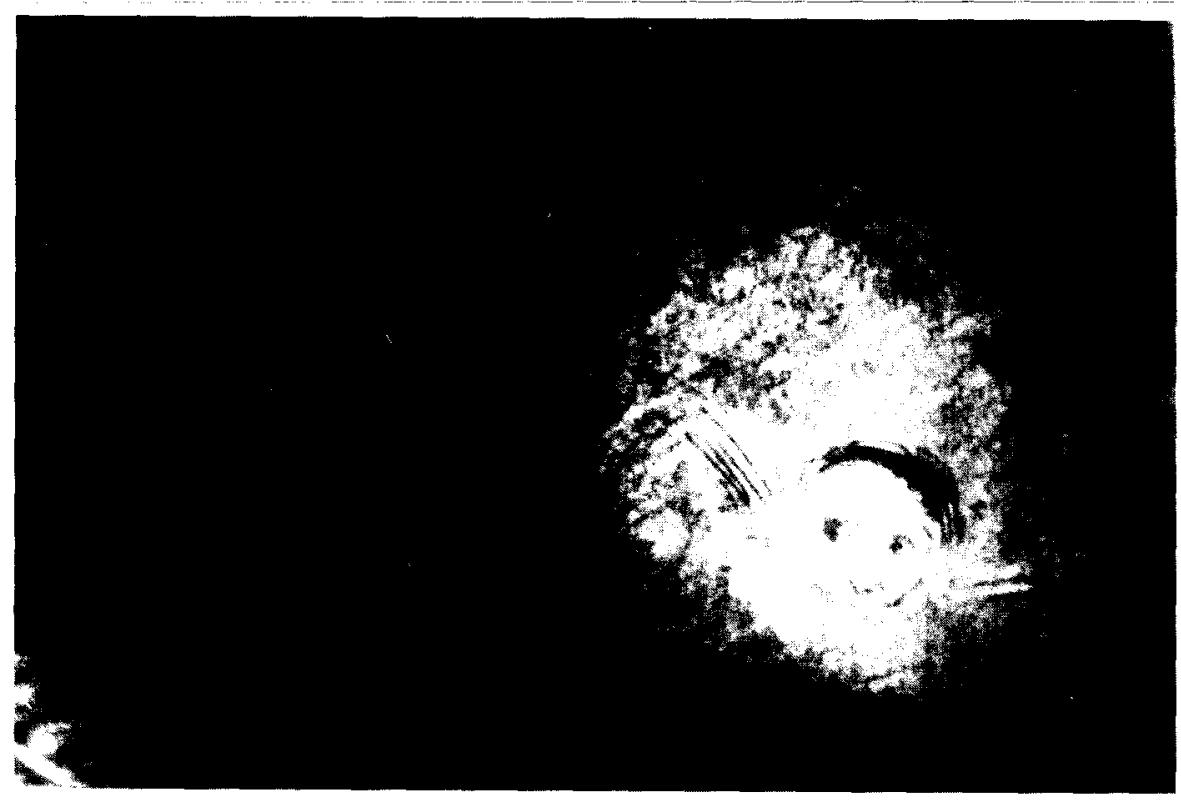

Fig. 2. "Pequeña cabeza alada en la noche", $s / t$.

parte, el uso del blanco y negro le unia a la tradición más experimental del siglo xIX, de Blake a Goya.

Explicaciones a la iconografía de Odilon Redon se han dado varias. Sin duda, son muchas las fuentes de las que bebió: Armand Clavaud le introdujo en el mundo de la botánica y del microscopio, pero también le aficionó a la cultura hindú, la religión budista, la poesía de Baudelaire... todo muy Fin de Siglo. Por otra parte, aprendió la técnica del grabado de Rodolphe Bresdin. Fue este medio el que cultivó de forma más intensa hasta la década de los 90 y quizá en el que obtuvo mayores logros. Su obra gráfica es de una riqueza y una fuerza impresionantes. Los temas generalmente tienen que ver con el mundo del sueño, de los orígenes y, por supuesto, de la noche. Realizó también algunos homenajes a creadores que le habian marcado, como Goya o E. A. Poe. Todo, por lo tanto, dentro de la tradición irrealista del XIX. Lamentablemente, su obra gráfica no ha venido a Madrid, a la exposición de la Fundación Juan March, por una razón que implica una cualidad: la comisaria de la exposición temió mostrar dibujos y óleos con obra gráfica, pues los primeros iban a desmerecer frente a la tremenda fuerza de la segunda. 
Michael Wilson ${ }^{17}$, muy dado a lo psicológico, explica el gusto por la imagen nocturna de Redon basándose en su infancia enfermiza y en las largas estancias en la siniestra casa de Peyrelebade, así como, por otra parte, funda el cambio operado por Odilon en los 90 -abandono progresivo del negro para ir hacia el color- en el creciente éxito que conoce el artista en esta época y en la venta de la citada casa familiar, supuesto escenario de sus pesadillas infantiles. Sin duda es esta una interpretación demasiado simplista y nos inclinamos más bien por mantener que tanto una actitud como la otra son, amén de producto de su personalidad, deducibles del entorno. No hay que olvidar que Redon vivia inmerso en el Paris simbolista tan dado a las influencias románticas de Delacroix y de Wagner.

Una de las notas más románticas de su carácter fue su obstinación en negarse a que se analizaran sus obras. Para él, el concepto estaba muy alejado de la obra artística. El Arte no debe nada a la Filosofía. La belleza no necesita de explicaciones, y menos de etiquetas o encorsetamientos. Por eso, también siempre aborreció el titular las obras, pues, según él, nombrar un objeto significaba sustraerle tres cuartas partes de su esencia y de su poesia, pues ésta consiste en ir descubriendo poco a poco el objeto, como en un sueño ${ }^{18}$.

Huysmans, como otros, también comparte esta aversión al concepto: muchos años después de publicar $A$ Rebours, declarará que esta novela había sido realizada sin un plan previo, sin un concepto, "sin nada".

En la parte de la colección de lan Woodner que ha venido el año 1990 a Madrid, hay, exceptuando obra gráfica, una representativa muestra de la obra de Redon: óleos, pasteles y sobre todo, dibujos componen el abanico de temas que el artista trata.

Ante todo, hay que decir de ellos que todos tienen un aura de misterio, tanto si el autor plasma la terrible visión de los dientes de Berenice como si se trata de un jarrón con flores. Todo está como sonado, entrevisto. Por otra parte, y dado el brusco cambio que Odilon dio a partir de los años 90 con la introducción del color y de otros temas, habrá que puntualizar que negó que sus primeras obras, tan terribles, fueran producto de la infelicidad y la desesperación. Muy al contrario, se declaró en su diario $A$ soiméme de 1915 , feliz y en paz. "No soy un prisionero,

${ }_{17}$ WILSON, M., Nature and immagination. The work of Odilon Redon, Oxford, Phaidon, 1978, pág. 60.

${ }^{18}$ Opiniones tomadas de la cita directa de O. R. en WiLSON, obra citada, pág. 30. 
mi alma no es negra, bendigo la vida que me hace amar el sol, las flores $y$ todo el esplendor del mundo externo" 19 .

Este cambio puede muy bien explicarse por el contacto con el joven grupo Nabis y Emile Bernard, tras el que va volviendo al color. Esto supone un gradual alejamiento de las primeras obras. Quizá ese no perder el contacto con la tierra pese a su irrealismo, explique este aparentemente brusco cambio.

Dejando aparte los espléndidos jarrones de flores, que demuestran la gran calidad técnica de la pintura de Redon, hay otros temas que se ajustan más a aquello de lo que estamos hablando, cómo son las visiones. ¿Son visiones? ¿Son sueños? Son algo indeterminado que está en nuestro subconsciente. Son todas imágenes en las que una sola figura es protagonista. Puede ser un hombre esqueleto o una aparición de un ser confuso (Fig. 3) ${ }^{20}$. Todas, fuera del espacio, fuera de nuestra conciencia.

Puede haber hombres vegetales, como el hombre cactus, o mujeres inmersas en el mundo vegetal y acuático, como sus numerosas Ofelias. O puede haber cabezas misteriosas, voladoras. (Fig. 2). Sin embargo, las más terribles son las visiones infernales, terribles, como "Visión. Dientes de Berenice" y "A través de la grieta del muro se proyectó una calavera». Éstas resucitan toda la tradición romántica del más puro terror "a la Mary Shelley".

Son frecuentes también los temas clásicos: "Orfeo", "Las tres parcas", "Carro de Apolo"... todos tratados con igual sensación de ensoñación y todos muy en la línea del tratamiento finisecular. Son mitos, sobre todo el de Orfeo, que resucitan ahora, pues vuelven a tener una gran vigencia.

Los astros, el fin de un mundo conocido y antiguo, el ensimismamiento de ese eclipse que describia Stifter parecen estar en "Sol negro" (Fig. 4).

La mujer terrible y dura tiene pocos ejemplos aquí. Redon más bien alude indirectamente a ella en "Cabeza de san Juan Bautista". La idea de la decapitación como castración es un tema muy recurrente en estos

19 Bacou, R., Odilon Redon, Ginebra, ed P. Caille, 1956.

${ }^{20}$ Esta obra parece ilustrar las palabras de J. R. Jimenez: "Dos veces he visto en mi vida, a las altas horas de la noche, un hombrecillo extraño cuya mirada fija y siniestra me ha helado el alma..." Tomado de AA. VV., obra citada, pág. 11. 


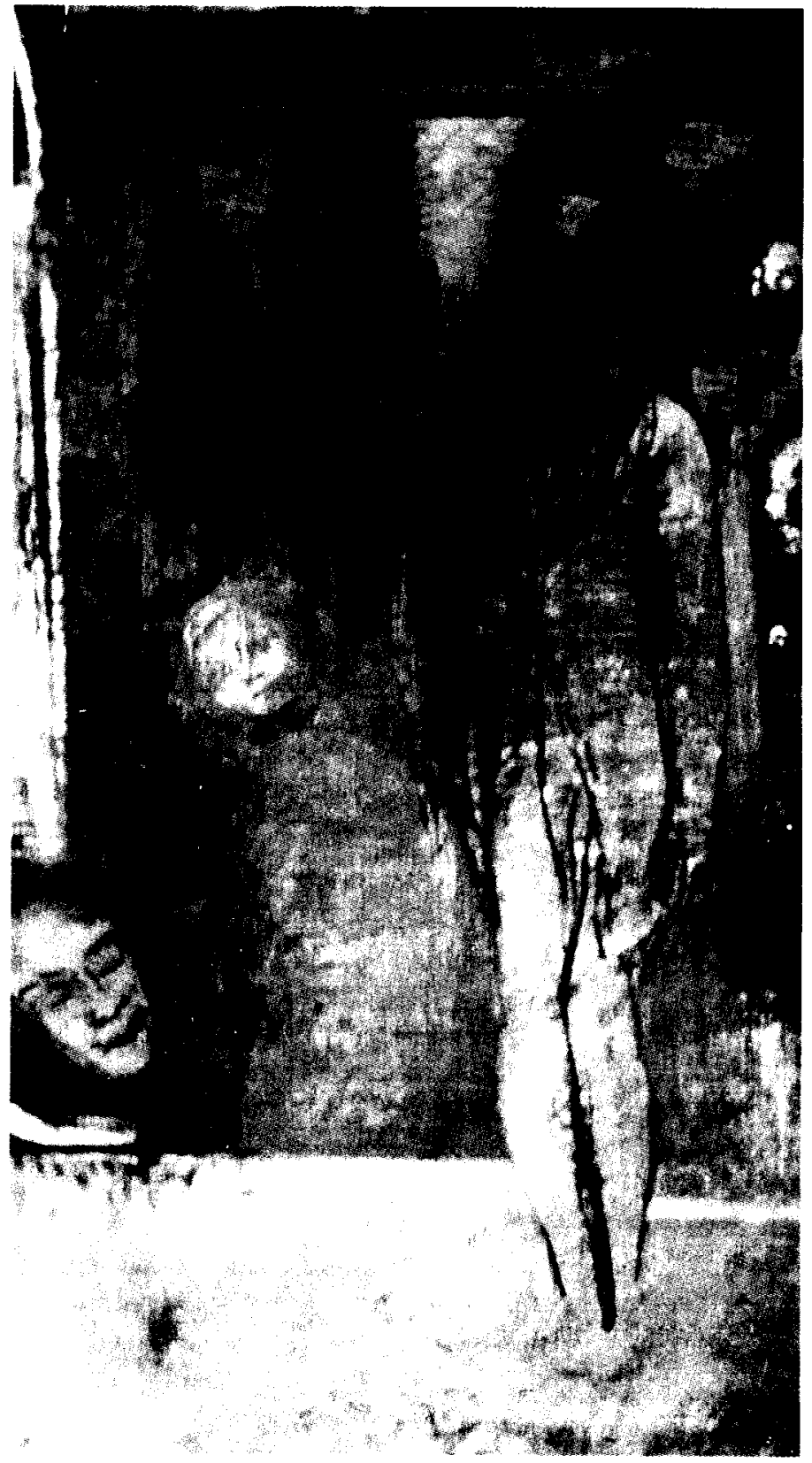

Fig. 3. "Aparición», s/t. 
Noches, sueños y apariciones de un fin de siglo. Odilon Redon ...

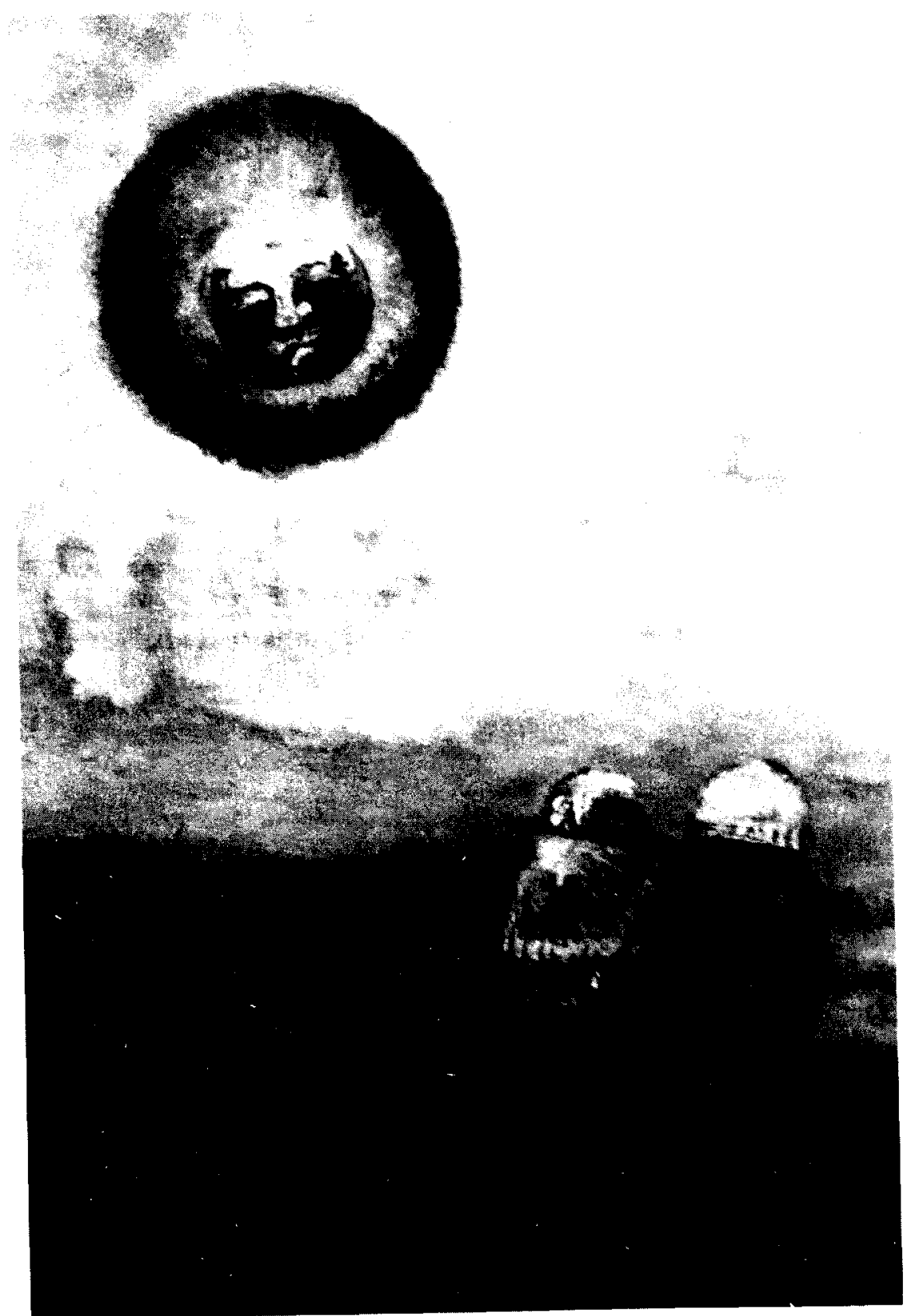

Fig. 4. "Sol negro", s/f. 


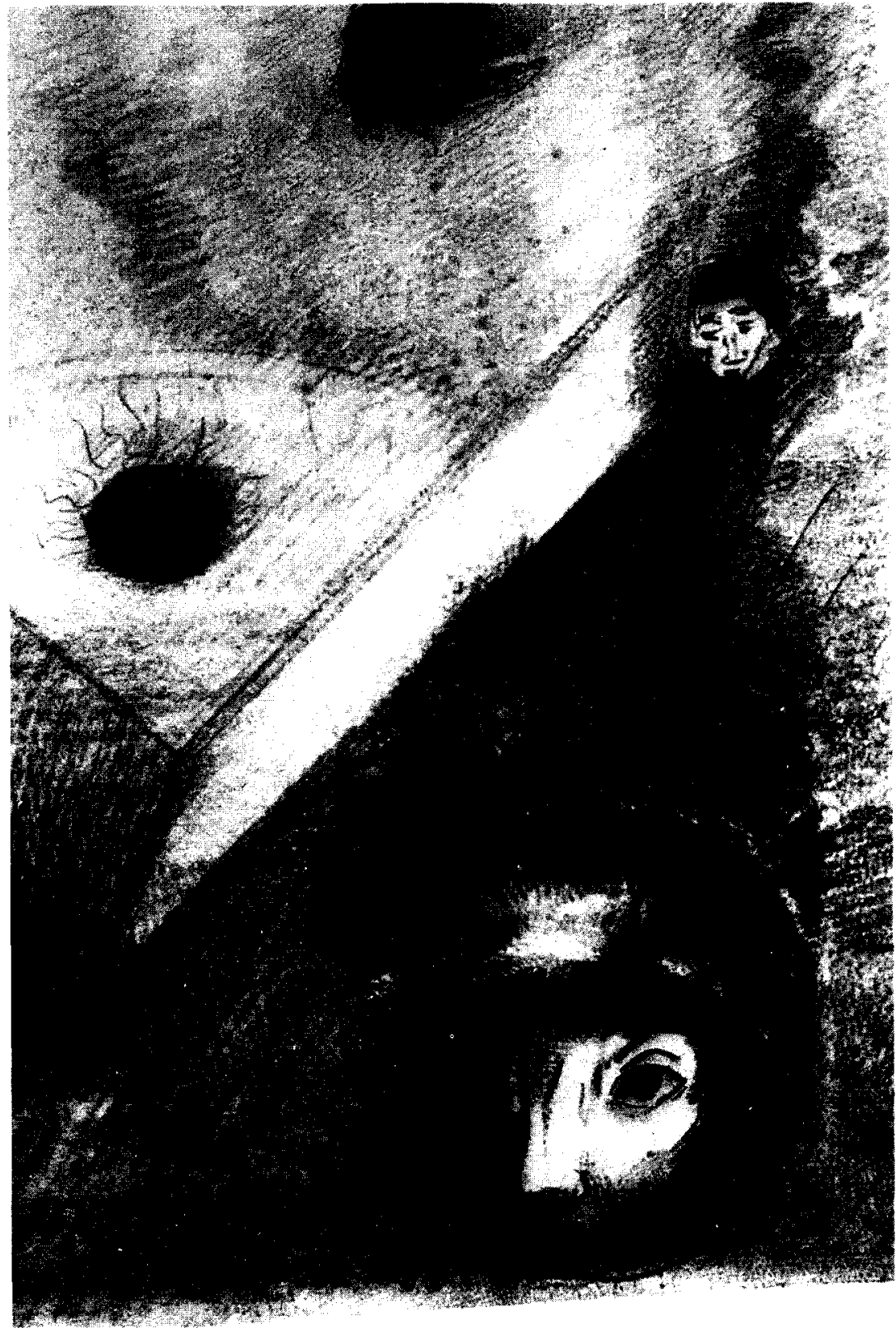

Fig. 5. "Sobre el fondo de nuestras noches", s/t. 
Noches, sueños y apariciones de un fin de siglo. Odilon Redon ...

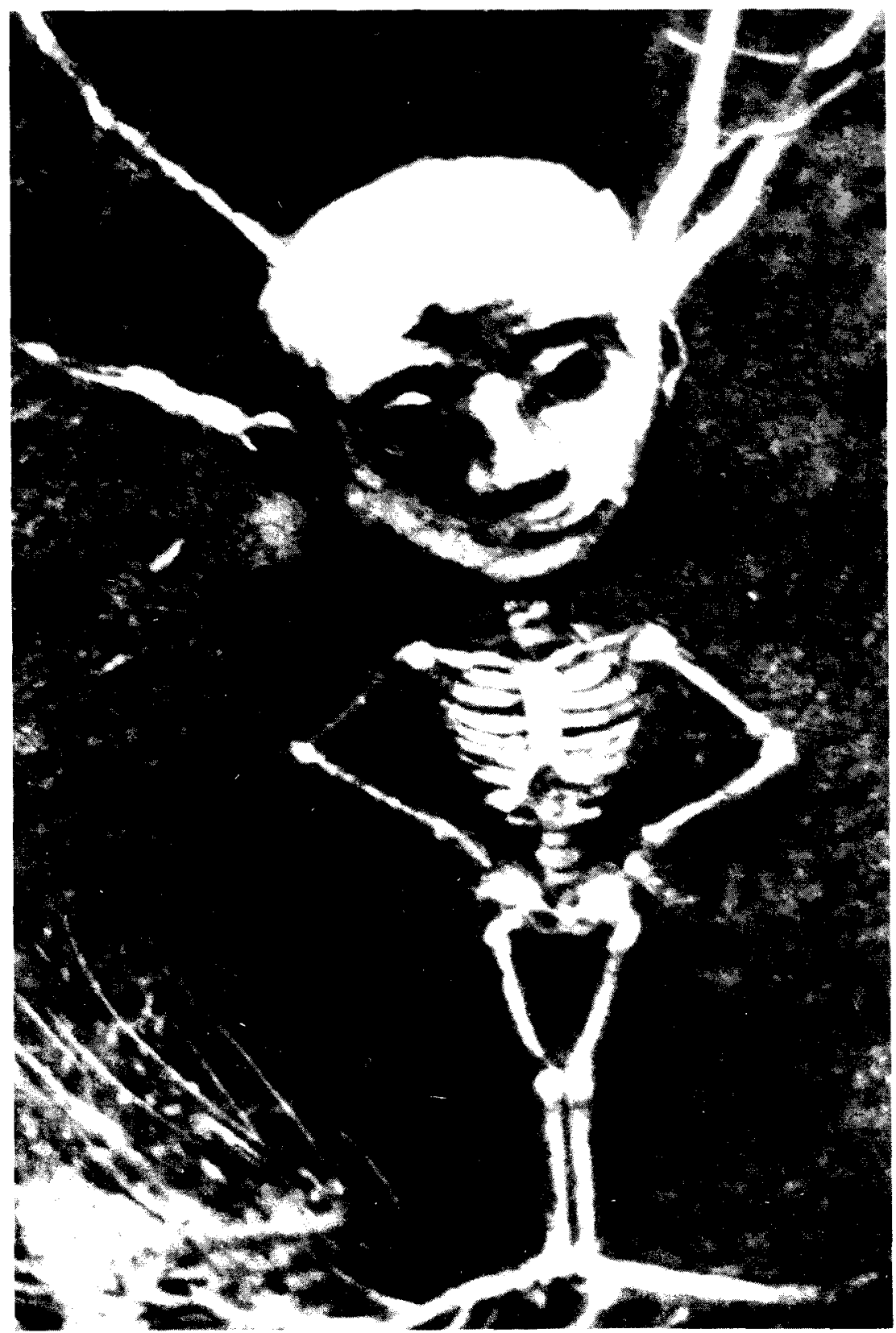

Fig. 6. "El hombre esqueleto", s/f. 
años (Freud, Klimt). Si no hubo una influencia directa de unos sobre otros, desde luego todos respiraron en un mismo aire.

Junto con su llegada al color, Redon se reconcilia con la mujer. Ya no es la malévola Salomé, sino la criatura delicada que recuerda a los retratos florentinos del Renacimiento.

Redon se distingue, como ya hemos repetido, de otros contemporáneos, por ese afan de trascender la realidad. Realmente, incluso van Gogh, preocupado por lo sujetivo, conserva una cierta dosis de realismos en sus paisajes.

Odilon fue guia del grupo simbolista junto a Gustave Moreau, quien también toca el mundo de lo irreal, generalmente tomando la imágen mitológica como base para sus ejercicios. El hará que toda una generación de alumnos artistas, que llega hasta Matisse, tenga en cuenta la realidad trascendente. Seria ambicioso realizar aquí un análisis detallado del tratamiento de la noche en toda la serie de artistas de este grupo estético. Sin embargo, habría que decir que realmente en este momento se distingue muy claramente la tradición del norte de la mediterránea. Todo el filón irrealista de la primera, que cuenta con importantes exponentes como Böcklin o Khnopff, derivará en la amargura, la angustia y el miedo atávico de $\mathrm{E}$. Munch y en la provocación, la agresión al espectador de las fuertes imágenes de un Ensor, unos de los artistas más originales del momento en su tratamiento de la noche.

Por contra, la tradición mediterránea se agrupa en torno a la figura de Gauguin y más tarde, de Serusier. Ellos también gustarán de las imágenes de sueños, pero de forma mucho más dulcificada, con referencias constantes a la Arcadia. No hay que olvidar que ser nabi significaba ser una enamorado de la belleza y el bien.

Odilon Redon confesaba al final de sus días que el color tenía un brillo que le relajaba. Hoy le recordamos más por sus "Negros" que por sus pasteles. Quizá se trate, como él mismo sugeria, de abandonarse simplemente en la noche de la contemplación. Quizá sea verdad, o quizá lo fué, que el corazón tiene razones que la Razón no entiende. 